OPEN ACCESS

Check for updates

\section{Bend it like Beckham or fix them like Florence-proportional representation of healthcare in New Year honours: an observational study}

\author{
John A Emelifeonwu, ${ }^{1}$ James E Hazelwood, ${ }^{2}$ Oscar Nolan, ${ }^{3}$ Emma Sharland, ${ }^{3}$ Anna O'Donald, ${ }^{3}$ \\ Alison Peet, ${ }^{4}$ Ricky Frazer ${ }^{5}$
}

\section{ABSTRACT}

OBJECTIVES

To compare the proportional representation of healthcare workers in receipt of New Year honours (NYHs) with workers in other industries and to determine whether the NYH system has gender or

\section{DESIGN}

Observational study of the UK honours system with a comparative analysis of proportional representation of the UK workforce and subgroup analyses of gender and geographical representations.

\section{PARTICIPANTS}

Recipients of NYHs from 2009 to 2018.

\section{MAIN OUTCOME MEASURES}

Absolute risk of receiving an NYH based on industry, gender, or region of the UK. Relative risk of receiving an NYH for services to healthcare compared with other industries.

\section{RESULTS}

10989 NYHs were bestowed from 2009 to 2018, $47 \%$ of which were awarded to women. 832 awards (7.6\%) were for services to healthcare. People working in sport and in the arts and media were more likely to receive NYHs than those working in healthcare (relative risks of 22.01 (95\% confidence interval 19.91 to 24.34 ) and 5.84 (5.31 to 6.44), respectively). There was no significant difference between the rate of receiving honours for healthcare and for science and technology $(\mathrm{P}=0.22) .34 \%$ (3741) of awards were issued to people living in London and in the southeast of England, and only 496 of 1447 (34\%) higher order awards (knighthoods, damehoods, companions of honour, and commanders of the order of the British empire) were received by women.

\section{CONCLUSIONS}

In relation to the size of its workforce, a career in healthcare is not as "honourable" as careers in certain other industries. Geographical and gender biases might exist in the honours system. geographical biases.

\section{WHAT IS ALREADY KNOWN ON THIS TOPIC}

The Queen and the government's Cabinet Office are the "fountains of honour" in the United Kingdom

Those closest to the fountain are most likely to get splashed

\section{WHAT THIS STUDY ADDS}

The fountain appears to disproportionately splash politicians, those in arts and media, and sportspeople over healthcare workers and people working in science and technology

\section{Introduction}

The UK honours system recognises people who have "committed themselves to helping and serving the UK" (box 1). The New Year honours (NYHs) are appointments in recognition and reward of excellence in the work or charity (or both) of citizens of the UK and Commonwealth countries. They have been awarded as part of the New Year celebrations since 1890 by, or in the name of, the reigning monarch. ${ }^{1}$ The public nominates people for honours, and nominees are overseen by the Cabinet Office's honours and appointments secretariat. Honours can be received in eight sectors: community, voluntary, and local services; arts and media; health; sport; education; science and technology; business and the economy; and civil or political services.

Some awards, known as orders, exist for select groups, including the Order of the Bath for senior civil servants and military officers, the Order of St Michael and St George for diplomats and those serving the UK abroad, and the Royal Victorian Order for those who have served the Queen or monarchy in a personal way.

The honours system has been criticised for being biased in favour of those in "Royal circles," including politicians and civil servants-the reigning monarch is the "fountain of honour," and those around the fountain are more likely to be "splashed." In recent years, commentators have said that this bias extends to connected people, particularly celebrities. ${ }^{23}$ Amid concerns of cronyism and a broken system, the government has vowed to review the honours system to ensure that it "rewards genuine public service." 4 The NHS is a genuine public service that employs approximately 1.5 million people and is ranked among the best in the world in terms of its quality, accessibility, and efficiency. ${ }^{5}$ The health sector provides approximately $7 \%$ of the entire UK workforce. ${ }^{6}$ Most are unable to influence the honour system. We determined how the proportion of NYHs awarded for healthcare compared with the proportions awarded to workers in other industries in the UK and whether there were any gender or geographical differences in the NYHs awarded.

\section{Methods}

Data

NYH list

A list of the recipients of NYHs is available on the Cabinet Office's website. ${ }^{7}$ It contains the names of all recipients of an honour, the order of the honour including its title, the sector or categories to which the recipient has provided outstanding services, and 


\section{Box 1: The UK honours system}

- The UK honours system is a series of honours that are awarded by the monarch to reward achievements (of varying degrees) in public life, giving the recipient public recognition and the use of the appropriate postnominal letters

- Recipients are notified in the biannual honours lists, at New Year or around the monarch's official birthday, and have the honour bestowed by a member of the Royal family at one of approximately 60 ceremonies throughout the year

- Nomination for an award can be made only by someone else and must include details of the work deemed rewardable and any recognition previously received

- A nomination must be further supported by letters from two people who know the nominee personally

- Nominations are assessed by the committees comprising senior civil servants and members independent from government

- Individual committees exist for different activities (arts and media, sport, and so on), which approve awards in their fields, before sending for the final approval of the main committee

\section{Analysis}

We matched each sector of service to the relevant category of the ONS report as follows: arts and media was matched with art, recreation, and entertainment; civil and political services was matched with public administration and defence and compulsory social security; health was matched with human health activity; science and technology was matched with professional scientific and technical activities; education was matched with teaching and education professions; and sports was matched with fitness and sports occupations. Honours for voluntary and community services were omitted from this analysis as there were no direct matches with ONS workforce figures.

We extracted workforce data from the final quarter of each year (2009-18). Five authors (JEH, ON, ES, AO'D, JAE) independently extracted ONS and NYH data from two years each, and the data was then cross checked by a different author. Disputes were resolved by consensus.

The relative risk (RR) of receiving an NYH for each industry compared with healthcare was calculated using the equation:

$$
\mathrm{RR}=\mathrm{AR} \text { (industry) } \div \mathrm{AR} \text { (healthcare) }
$$

Where AR (absolute risk) is the number of NYHs for a sector divided by the number of people employed in the industry (size of workforce). A similar equation was used to compare industry differences in the proportion of higher order awards. RRs and 95\% confidence intervals were calculated using the Epitools package in $\mathrm{R}^{10}{ }^{11}$ The significance level was set at $\mathrm{P}<0.05$ (two tailed) when comparing workforces and when comparing proportions of higher order awards.

Pearson's chi squared test was used to compare gender differences in the proportion of higher order awards received. We determined the gender of recipients either by their name or by the gender prefix used in the NYH list. Rarely, internet searches were used to determine gender.

\section{Patient and public involvement}

No patients were involved in setting the research question or the outcome measures, nor were they involved in developing plans for design or implementation of the study. No patients were asked to advise on

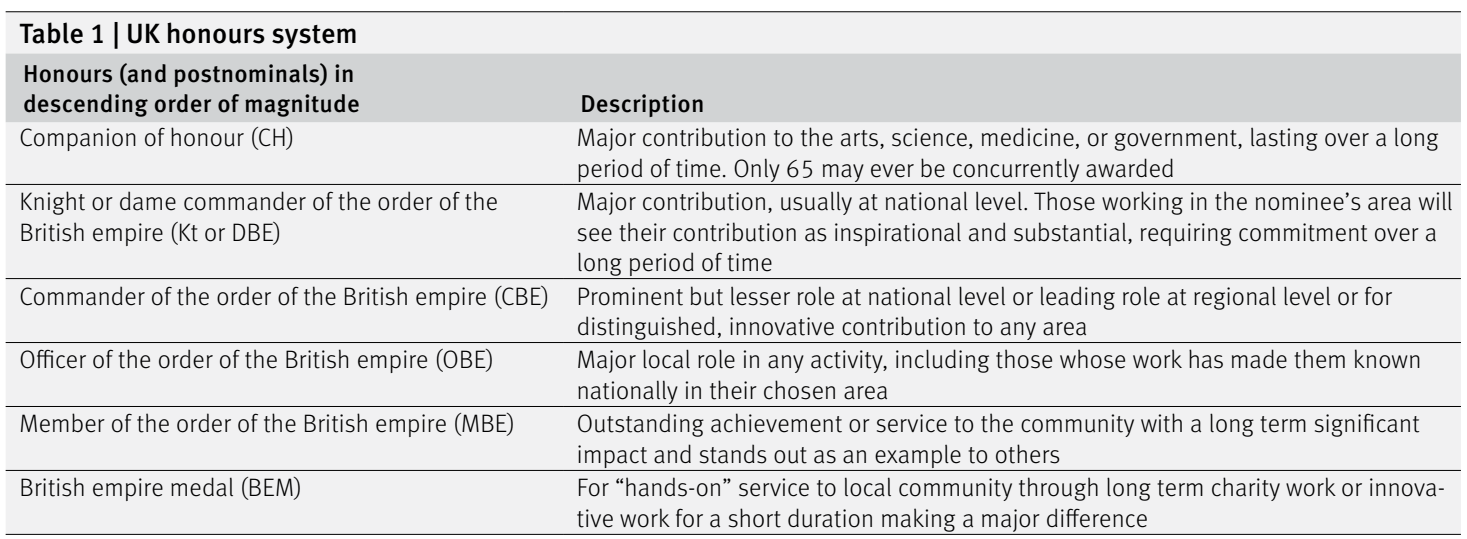


interpreting or writing up results. There are no plans to disseminate the results of the research to patients or study participants.

\section{Results}

A total of 10989 NYHs were bestowed between 2009 and 2018 (table 2). We were able to determine the gender of 10979 recipients; 5166 were female $(47.1 \%)$ and 5813 were male $(52.9 \%)$. The total cohort comprised $17 \mathrm{CHs}, 81$ Orders of the Bath, 343 damehoods and knighthoods, 3 Orders of St Michael and St George, 1006 CBEs, 2353 OBEs, 5310 MBEs, and 1876 BEMs.

The proportion of awards bestowed for each of the eight sectors for each year is shown in figure 1 . The most common sectors were community services (2989; 27\% of all awards) and voluntary and local services (2025; $18 \%)$. Then, 1203 (11\%) were bestowed for services to education, 975 (9\%) for services to business and the economy, 1038 (9\%) for civil and political services, 832 (8\%) for services to health, 795 (7\%) for services to media and the arts, 703 (6\%) for services to sports, and $419(4 \%)$ for services to science and technology. Notably, the proportion of awards for sports spiked in the years after Olympic games (2013 and 2017) (fig 1).

\section{Differences in relative risk between honours for} health and other industries

A total of 832 NYHs were awarded for services to health between 2009 and 2018; 450 (54.1\%) recipients were female. Healthcare honours constituted $7.6 \%$ of all awards received in that period. Doctors received 34.4\% (286) of these awards, whereas nurses and allied health professionals each received $14.5 \%$ (121). The remaining $36.5 \%$ (304) were awarded to healthcare support staff such as management staff. The ONS estimates for the total UK healthcare workforce in the final quarters of each year ranged from 3846000 in 2009 to 4340000 in 2018.

The RRs of receiving an NYH for services to other industries compared with healthcare are shown in table 2. The RR of receiving an NYH for services to sport was 22.01 times higher than healthcare, arts and media was 5.84 times higher, business and the economy was 3.9 times higher, and civil and political services was 2.66 times higher. There was no significant difference between the rates of receiving an NYH for services to science and technology and for services to healthcare.

\section{Differences in the proportion of higher order honours bestowed}

There were 58 higher order awards issued for service to healthcare (CHs, knighthoods and damehoods, and CBEs). This was $6.9 \%$ of the total number of NYHs given for services to healthcare. This proportion was comparable to the proportion of higher order awards issued for services to arts and media $(6.3 \%, \mathrm{P}=0.58)$, education $(5.2 \%, \mathrm{P}=0.08)$ and science and technology $(8.4 \%, \mathrm{P}=0.4)$ (table 2).

Nearly $11 \%$ of awards received for services to civil and political services were higher order. This is significantly higher than the rate for healthcare (RR 1.56; $95 \%$ confidence interval 1.15 to 2.11 ; $\mathrm{P}=0.03$ ). Conversely, only $2.8 \%$ of honours for sports were higher order, which is significantly lower than for healthcare (RR 0.4; 0.25 to $0.67 ; \mathrm{P}<0.001$ ) (table 2 ).

\begin{tabular}{|c|c|c|c|c|}
\hline & $\begin{array}{l}\text { No of NYHs (No of } \\
\text { higher order) }\end{array}$ & $\begin{array}{l}\text { Average size of } \\
\text { workforce }(2009-18)\end{array}$ & $\begin{array}{l}\text { AR of } \\
\text { receiving NYH }\end{array}$ & $\begin{array}{l}\text { RR }(95 \% \mathrm{Cl}) \text { of receiving } \\
\text { NYH for services to sector } \\
\text { versus healthcare }\end{array}$ \\
\hline \multicolumn{5}{|l|}{ Gender: } \\
\hline Undetermined & 10 & & & \\
\hline \multicolumn{5}{|l|}{ Sector: } \\
\hline Arts and media & $795(50)$ & 6651000 & $1.20 \times 10^{-4}$ & $5.84(5.31$ to $6.44 ; P<0.001)$ \\
\hline Business and economy & $975(47)$ & 12221000 & $7.98 \times 10^{-5}$ & $3.9(3.59$ to $4.28 ; P<0.001)$ \\
\hline Civil and political service & $1038(113)$ & 19089000 & $5.44 \times 10^{-5}$ & $2.66(2.43$ to $2.91 ; P<0.001)$ \\
\hline Healthcare & $832(58)$ & 40701000 & $2.04 \times 10^{-5}$ & - \\
\hline Community services & 2989 & NA & NA & \\
\hline Voluntary and local services & 2025 & NA & NA & \\
\hline \multicolumn{5}{|l|}{ Order of honour: } \\
\hline Companion of honour & 17 & & & \\
\hline Knighthood/damehood & 343 & & & \\
\hline Orders of Bath & 81 & & & \\
\hline Orders of St Michael and St George & 3 & & & \\
\hline CBE & 1006 & & & \\
\hline OBE & 2353 & & & \\
\hline MBE & 5310 & & & \\
\hline
\end{tabular}




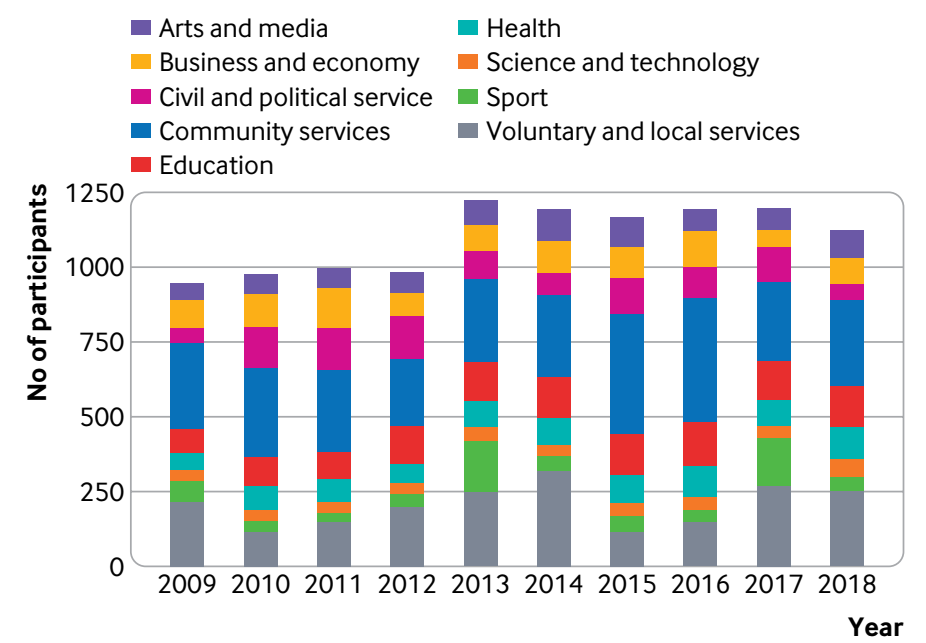

Fig 1 | Distribution (\%) of NYHs for each year from 2009 to 2018

The proportional representation of women in NYHs has improved over the period studied, but only about one third (496 of $1447 ; 34 \%$ ) of the higher order NYH recipients were female (fig 2). The rate of receiving higher order awards was significantly higher for men $(\mathrm{P}<0.001)$ (table 2).

\section{Geographical differences in awards}

We calculated the total number of NYHs received in each region of the UK (including health and nonhealth categories) and compared the average number of awards for people living in each region over the past decade (fig 3). In England, London (1944; 18\%)
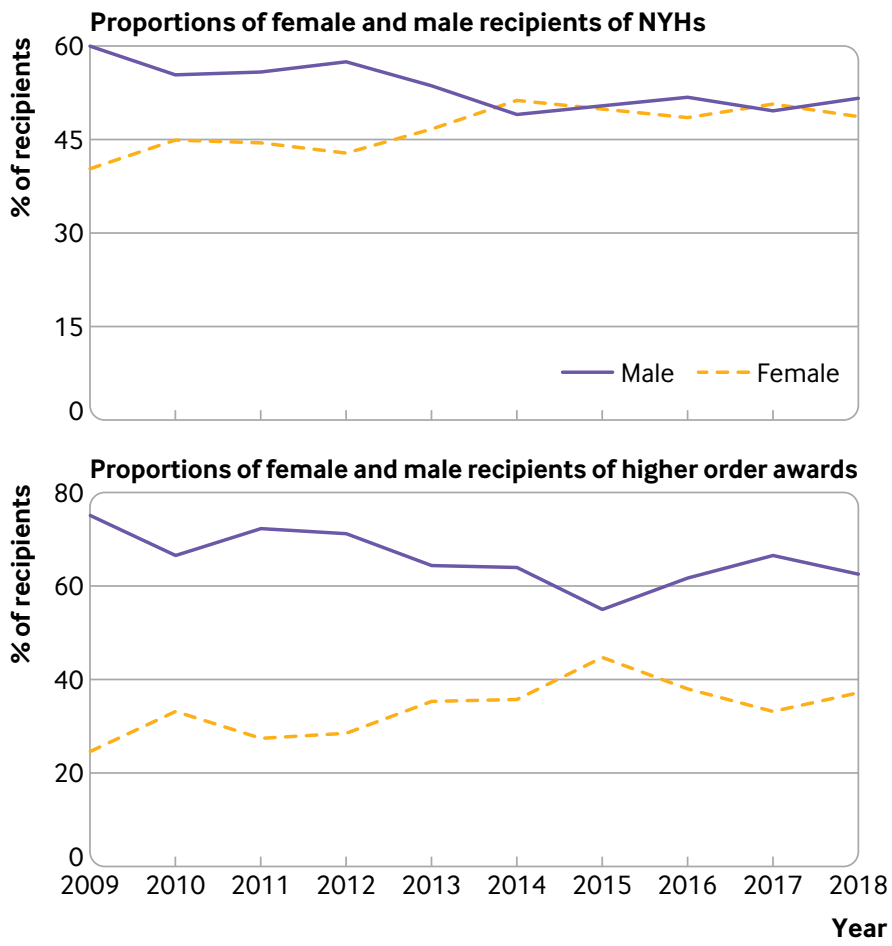

Fig 2 | a) Proportions (\%) of male and female recipients of NYHs from 2009 to 2018. b) Proportions (\%) of female and male recipients of higher order NYHs from 2009 to 2018 and the south east $(1797 ; 16 \%)$ received the highest numbers of NYHs, corresponding to an average of 23 NYHs per 100000 persons and 20 NYHs per 100000 persons, respectively. The south west of England was also well represented compared with the rest of England (16.5 NYHs per 100000 persons). The east of England received the lowest number per population (11.8 per 100 000), and there was no significant difference between the number of NYH recipients in east England, Yorkshire (11.9 per 100 000), and the Midlands (12.5 per 100000 for West Midlands and 13.1 per 100000 for East Midlands).

People in Scotland received approximately 9\% (1019) of the NYHs, corresponding to an average of 19 NYHs per 100000 population. People in Wales received approximately 5\% (562) of all NYHs, corresponding to approximately 18 NYHs per 100000 . Northern Ireland received the highest proportion throughout the UK, with approximately $38 \mathrm{NYHs}$ per 100000 population. Approximately 0.6\% (78) of all NYHs were awarded to non-UK residents (in our data this included residents of the Channel Islands and the Isle of Man).

\section{Discussion}

Principal findings

In this phaleristic study, we compared the proportional representation of various industries in the NYHs from 2009 to 2018. We found that the rates of receiving an award were significantly higher for people working in sport, arts and media, and to a lesser degree in the civil and political services and in business, than for people working in healthcare or in science and technology. We also found geographical differences, with 34\% of awards bestowed on people living in London or southeast England. Finally, although proportional representation has improved for women over the past decade, the proportion of women receiving the higher order awards was significantly lower than men.

\section{Is the honours system biased?}

In the period examined, the proportions of recipients from each industry each year has remained roughly similar (except for awards for sports, which increased markedly after each Olympic year). Perhaps the Cabinet Office uses quotas to determine how many awards are received in each category. Quota systems negatively bias groups with larger workforces due to dilution. The NHS is the fourth largest employer in the world with approximately 1.5 million employees, and many more people work in private health in the UK. ${ }^{12}$ Assigning the same proportion of NYHs to the health industry as other smaller industries would reduce the chances of people in healthcare receiving an award. The higher rates of receiving an $\mathrm{NYH}$ in other industries than in healthcare might therefore be due to dilution rather than bias. The science and technology sector, however, is under-represented. This group has a similar size workforce to civil and political services and nearly double the size of sport but was less likely to receive an NYH than both industries. 


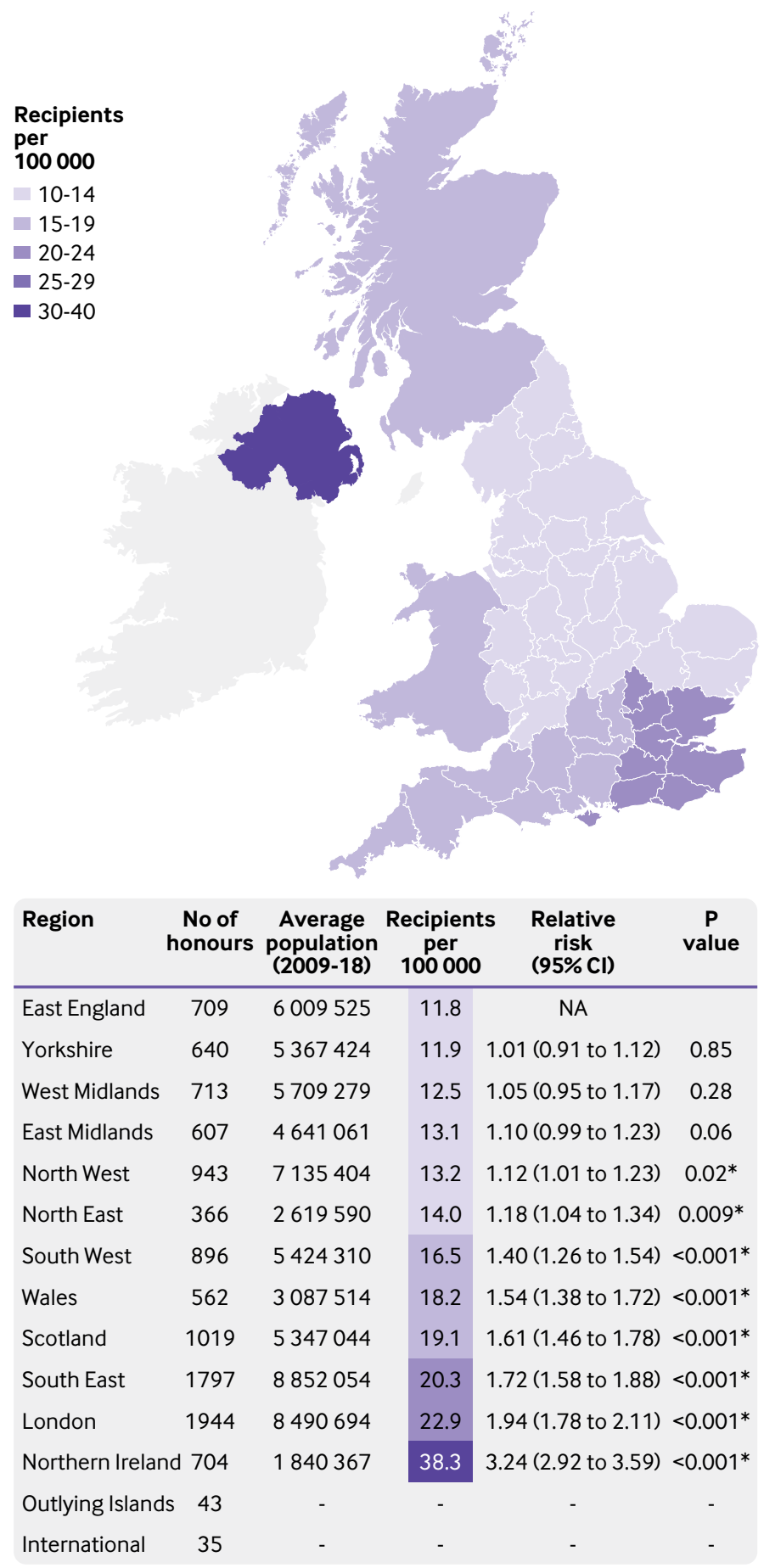

Fig 3 | a) Heat map showing the number of NYH recipients per 100000 population in regions of the UK between 2009 and 2018. b) Number of NYHs received in regions of the UK and corresponding average rate of NYHs received in each region compared with the east of England, which received the lowest per population number of NYHs

Gender differences might be due to bias. This has been tackled to some extent by the increasing proportion of women recipients over the past 10 years (fig 2). But the low number of women receiving the higher order awards compared with men indicates that more needs to be done. Gender inequalities are not unique to the honours system. International evidence shows persistent under-representation of women in the film industry, ${ }^{13}$ corporate leadership, ${ }^{14}{ }^{15}$ and medicine. ${ }^{16}$ A 2017 study analysed the recipients of awards from the American Academy of Physical Medicine and Rehabilitation over the past 48 years, finding that women were substantially under-represented and that, strikingly, no female physician received an award in the most prestigious categories in 40 of the 48 year history of the ceremonies. ${ }^{16}$

Initiatives have been developed to target gender inequity in different industries. ${ }^{17-19}$ But clearly more needs to be done. The Cabinet Office has recognised the under-representation of women and vowed to "step up efforts in outreach work, targeting women's business and community networks to raise awareness of the [honours] system, and encourage nominations from those groups."9

The Parliamentary Public Administration Select Committee's 2012 report criticised the honours system as being focused on rewarding people for simply "doing their day job." ${ }^{20}$ In particular, it noted that Whitehall bureaucrats and other senior figures, such as council chief executives, traditionally made a strong showing in the honours. The report said that too few honours were being awarded to ordinary citizens for the extraordinary contributions they make to their communities, which is what the system should be for. The report recommended that there should be no automatic honours for people who hold a certain post or for celebrities and sports stars at a certain level, which "too often seemed to still be the case." Our results show that this over-representation probably exists, particularly in sport, arts and media, and civil and political services compared with healthcare, science and technology, and to a lesser extent education.

\section{Weaknesses}

The ONS workforce data that we used to determine the proportion of NYHs in each industry are estimated using surveys of businesses and might not be entirely accurate. They are, therefore, a potential source of variation. Furthermore, the sector of service for NYHs might not correlate with the industry that the person works for-someone who works in education but has a voluntary role in healthcare, for example, might receive an award for services to health. We have considered the workforce data for each year independently of the other years. This approach does not take into account the proportion of people who already have an NYH in each industry and, therefore, might underestimate the proportion of recipients in each industry.

NYHs are awarded based on nominations from the public, so the differences in the proportions from different industries might simply reflect the referral practices of that industry. Thus, people in industries that work closest with the government and Cabinet Office (civil servants, politicians, those in the media) are more likely to refer a colleague for honours than people in healthcare. We contacted the Cabinet Office for a breakdown of nomination statistics, but this information was not available because of the rolling nature of nominations (a person might receive an 
award in a later round to the one in which they were nominated). This makes it difficult to calculate the nomination-to-award ratio for different categories. For completeness, we could conduct a survey of honours' nomination practices between different industries to determine whether people in some industries are more likely to nominate a colleague than others.

\section{Conclusion and policy implications}

We found that the rates of receiving an NYH are higher in some industries (arts and media, business and the economy, civil and political sciences, education, and sport) than in healthcare. The NHS is persistently voted among the best healthcare systems in the world. This is possible because of the extraordinary contributions being made by ordinary people working in healthcare-the very reason the honours system is alleged to exist. This needs to be reflected in the NYHs and may increase morale in the struggling NHS.

Competing interests: All authors have completed the ICMJE uniform disclosure form at www.icmje.org/coi disclosure.pdf and declare: no support from any organisation for the submitted work; no financial relationships with any organisations that might have an interest in the submitted work in the previous three years; no other relationships or activities that could appear to have influenced the submitted work.

Transparency: The corresponding author affirms that the manuscript is an honest, accurate, and transparent account of the study being reported; that no important aspects of the study have been omitted.

Contributors: All authors contributed to the planning, conduction and reporting of the work described in this article. JAE is responsible for the overall content as guarantor and accepts full responsibility for the work. The corresponding author attests that all listed authors meet authorship criteria and that no others meeting the criteria have been omitted.

Funding: None of the authors are grant holders, nor did any of the authors receive any funding for this study.

Ethical approval: Ethical approval was not required for this study Data sharing: No additional data available

This is an Open Access article distributed in accordance with the Creative Commons Attribution Non Commercial (CC BY-NC 4.0) license, which permits others to distribute, remix, adapt, build upon this work non-commercially, and license their derivative works on different terms, provided the original work is properly cited and the use is noncommercial. See: http://creativecommons.org/licenses/by-nc/4.0/.

1 Morrison J. Essential public affairs. 2015.

2 Liddle R. At least David Beckham has exposed the honours system for the sham it really is: The ugly attitude revealed in his emails is surely shared by any number of celebrities. Spectator 2017. www.spectator. co.uk/2017/02/at-least-david-beckhams-shame-shows-up-thehonours-system-too

3 McCartney M. Margaret McCartney: Dishonourable New Year honours. BMJ 2016;352:i28. doi:10.1136/bmj.i28

4 Maidment J. Theresa May vows to overhaul honours system to ensure it "rewards genuine public service" amid cronyism concerns. Telegraph 2017 May 18 https://www.telegraph.co.uk/ news/2017/05/18/theresa-may-vows-overhaul-honours-systemensure-rewards-genuine/

5 Schneider EC, Sarnak DO, Squires D, Shah A, Doty MM. Mirror, mirror: how the performance of the US healthcare system compares internationally at a time of radical change. The Commonwealth Fund 2017. https://interactives.commonwealthfund.org/2017/july/mirrormirror/

6 Full Fact. How many NHS employees are there? 2017. https://fullfact. org/health/how-many-nhs-employees-are-there/

7 Gov.uk. Nominate someone for an honour or award. https://www.gov. uk/honours/honours-lists

8 Office for National Statistics. JOBS03. Employee jobs by industry. https://www.ons.gov.uk/employmentandlabourmarket/ peopleinwork/employmentandemployeetypes/datasets/ employeejobsbyindustryjobs03

9 Cabinet Office. Fourth report on the operation of the reformed honours system 2015-19. 2019. https://assets.publishing.service. gov.uk/government/uploads/system/uploads/attachment_data/ file/807228/Report-on-the-Operation-of-the-Honours-System-Finalfor-Publication-1.pdf

10 R Core Team. R: A language and environment for statistical computing. R Foundation for Statistical Computing, Vienna, Austria. 2018. https://www.R-project.org/.

11 Aragon TJ. EpiTools: R Package for Epidemiologic Data and Graphics. 2012.

12 NHS Digital. NHS workforce statistics-September 2018. NHS Digital, 2018.

13 Lauzen MM. It's a man's (celluloid) world: on-screen representations of female characters in the top 100 films of 2014. http://fontanar2. cubadebate.cu/wpcontent/uploads/2015/02/2014_Its_a_Mans_ World_Report.pdf

14 Hesse-Biber S, Carter G. Working women in America. Oxford University Press, 2005.

15 Catalyst. Report: 2011 Catalyst census: Financial Post 500 women board directors. 2011. https://www.catalyst.org/research/2011catalyst-census-financial-post-500-women-board-directors/

16 Silver JK, Bhatnagar S, Blauwet CA, et al. Female physicians are underrepresented in recognition awards from the American Academy of Physical Medicine and Rehabilitation. PM R 2017;9:976-84. doi:10.1016/j.pmrj.2017.02.016

17 Kuhlmann E, Ovseiko PV, Kurmeyer C, et al. Closing the gender leadership gap: a multi-centre cross-country comparison of women in management and leadership in academic health centres in the European Union. Hum Resour Health 2017;15:2-7. doi:10.1186/ s12960-016-0175-y

18 Cook A, Glass C. Women and top leadership positions: towards an institutional analysis. Gend Work Organ 2014;21:91-103. doi:10.1111/gwao.12018

19 Ovseiko PV Greenhalgh T, Adam P, et al. A global call for action to include gender in research impact assessment. Health Res Policy Syst 2016;14:50. doi:10.1186/s12961-016-0126-z

20 House of Commons Public Administration Select Committee. The honours system. 2012. https://publications.parliament.uk/pa/ cm201213/cmselect/cmpubadm/19/19.pdf 